Review." WAC for the New Millenium: Strategies for Continuing Writing-AcrossThe-Curriculum Programs. Eds. Susan H. McCleod, Eric Miraglia, Margot Soven, and Christopher Thaiss. Urbana, IL: NCTE, 2001. 259-298.

Thaiss, Chrisopher. "Theory in WAC: Where Have We Been, Where Are We Going?" WAC for the New Millennium: Strategies for Continuing Writing across the Curriculum Programs. Eds. Susan H. McCleod, Eric Miraglia, Margot Soven, and Chrisopher Thaiss. Urbana, IL: NCTE, 2001. 299-323.

Carol Severino directs the Writing Center and the Writing Fellows Program and teaches courses that explore the relationships between writing, language background, culture, academic discipline, and pedagogy, also the topics of her research. She has taught courses in travel writing for Honors Seminar Programs and has published a number of her own travel essays. Carol was a Collegiate Teaching Award winner in 2003 and a Fulbright Scholar in Ecuador in 2008.

Matthew Gilchrist is the assistant director of the Writing Center at The University of Iowa and is a $\mathrm{PhD}$ student in Language, Literacy, and Culture.

\title{
Laila S. Dahan: Where Have all the Readers Gone? Improving Writing through Reading for EFL Learners in the Arabian Gulf
}

As a writing instructor at the American University of Sharjah in the United Arab Emirates, every day can be extremely challenging but, more often than not, very rewarding. The University is a not-for-profit private institution based on the U.S. model while being grounded in the local culture. We are fortunate to have over 70 nationalities represented among our student body of about 4000 students. Granted, not every nationality is in each class, but I do have the opportunity to encounter and teach many of these different nationalities and cultures every semester. I teach four writing courses each term with about 16-18 students in every class. These are introductory courses mainly for entering freshmen, some sophomores, and those who didn't pass the first time. Most of our students completed high school either at private international schools or public schools in their home countries. Our institution requires a TOEFL score of 530 or higher in order for a student to matriculate. Unfortunately, despite that score our students, as a general rule, do not arrive with the necessary skills needed to jump directly into writing. In fact, many of them reveal they have never written an essay in any language throughout high school. My colleagues and I have found that English as Foreign Language (EFL) students have problems with reading and writing skills in college for several reasons, including: insufficient first language (L1) and second language (L2) literacy backgrounds, lack of prior knowledge in various subjects, limited experience with active reading, and sometimes a negative attitude towards the value of academic reading and writing (Al-Issa and Dahan 17).

Prior knowledge seems to be one of the major reasons for the difficulties learners face with reading and writing at university. Our students have limited prior knowledge in fields and subjects that we would ordinarily assume they would have gained during high school. When discussing students' prior knowledge, I refer to their familiarity with subject matter, strategy knowledge, world, personal 
and cultural awareness, and finally knowledge of self. Despite the lack of prior knowledge found among our students, I never view this as a negative factor because the diversity they bring to the classroom in terms of cultural and educational backgrounds is certainly something to celebrate.

The variety of student backgrounds in addition to limited prior knowledge often makes teaching them to become good writers somewhat difficult. This is due to the amount of time needed to explain our many reading assignments. Without the requisite prior knowledge, it is difficult for students to write fluently and confidently. Since research has revealed that students need to activate their prior knowledge in order to gain a clear understanding of readings, our undergraduates are often at a distinct disadvantage. Our students definitely have limited prior knowledge about the western issues and topics found in some of our readings; however, they also have limited knowledge about their own historical and cultural background.

Therefore it is important for me to help them gain background knowledge through our readings in addition to helping them learn to question and become critical readers and thinkers. This leads to improvements in their writing skills to the point that their voices can be heard through their writing.

\section{The Department of Writing Studies (DWS)}

My department is the gateway for all new undergraduates to our University. They must pass through our writing sequence in order to move forward and be allowed to take their major courses. DWS produces and marks the English Placement Test (EPT) at the beginning of each term. Our method is double blind marking whereby students are put into one of three courses: Writing 001, Writing 101, or Writing 102. Writing 001 is a very introductory course that starts with paragraph writing. Students dislike being placed in this course as it has connotations of being remedial. Unfortunately, we have several sections of this course every term. Writing 101 is our introductory essay writing course to which most new students are assigned. Our last course is Writing 102 where students focus on writing argumentative papers, learn the fundamentals of the APA citation style, and practice writing critiques.

I have taught all three many times during the past six years. Over time I have noticed slight improvements in our students' writing abilities each time the University raises the TOEFL requirement, but I have never noted any major changes in the need for us to work extremely hard to teach writing and encourage reading.

\section{Bilingual Writers as "Global Souls"}

One thing which must be kept in mind when discussing our student writers is that they are bilingual writers and therefore are quite different from those students who write in their native language. "Global souls" are those raised in multicultural environments who feel comfortable crossing both linguistic and geographic borders ( $\mathrm{Li} 260$ ), and this is a fitting definition of our students. According to Li these global souls are empowered by both languages and claim multiple identities (260). However, I am not convinced that this is always a positive experience for them as multicultural writers; speaking in English is easier than writing in English.

Since our students possess at least two languages, it is often difficult for them 
to express their true feelings or beliefs in the second language: English. In fact, I believe my own students struggle while attempting to master English and become successful writers while using the second language ( $\mathrm{Li} 262$ ).

I am certain that for the majority of my students, writing in English takes much more effort than writing in their mother tongue. As Ferré notes, "writing in English is like looking at the world through a different pair of binoculars: It imposes a different mind-set" (qtd. in Li 262). While the students have many ideas, beliefs, and emotions in their native language, they are often confounded by having to put those thoughts into their second language.

\section{Empowering the Bilingual Writer}

One way to help my students feel that they can be successful writers is to empower them. I do this in order to give them more authority over their own learning, enable them to access resources, and gain control over their own lives.

As my students and I discuss essays, articles, books, and more in the writing classroom, they are given ample opportunities to articulate their own voices and convictions. I further encourage them to bring their opinions into their writing in response to the readings. By empowering them, I strive to give them the confidence to write well and try harder. Furthermore, empowerment means giving them choices about how they wish to tackle a writing assignment and how they choose to bring in their own inspirations. My objective is to ensure that my students value the goals of all their work (Nicolaidis and Koutroumpezi 185).

By adapting Paolo Freire's (1921-1997) approach to my classroom interactions, I seek to be a "co-learner" with my students. I work closely with them by taking an active part in their "culture" and experiences (Tropiano). In so doing they are empowered in terms of their learning and this comes forth in their written assignments.

\section{Steps Taken to Improve Student Writing}

At the beginning of each semester, I endeavor to determine my students' literacy from high school. I also attempt to understand their feelings towards reading and writing. Initially I give them opportunities to write about topics they are familiar with, hold importance for them, or touch them personally. I do this by making their first writing assignments narrative. Through these assignments I discover how they learned to read and write in their native language, how often they read any type of text, how much time they spent doing research in high school, etc. What I often find is that my students come from educational backgrounds that utilize memorization over critical reading, writing, or thinking. And it is these habits I must help them overcome. After becoming familiar with my students' literacy experiences, I can better determine which readings will be used in the course and what students will write in response to those readings.

\section{Reading as a Lost Art}

As all of us who teach writing know, an integral part of being a good writer rests upon the fact that we read a great deal. Furthermore, researchers in the field convey the importance of the relationship between reading and writing (Eskey 95; Reid 38; 
Tierney 571). Therefore the basis for all courses in the department involves reading paragraphs, texts, articles, essays, news clippings, etc. Virtually anything that can be used in the classroom to encourage reading in the quest for better writing is used. However, we are often thwarted in our efforts. Here amongst our many cultures we find that reading is neither celebrated nor looked upon as something university students do as a pastime. In fact, reading is often looked down upon as something that "must" be completed because it involves an assignment, but is rarely done for fun.

After grappling with this issue for many years, it has become apparent there are two clear reasons for this lack of reading. First, we must look at the age group we are dealing with. No matter where they came from, what country or culture, they had access to television, electronic games, movies, music, the internet, and cell phones - all of which make a book composed of sheets of paper look like something only their grandparents would enjoy. The second reason is quite often culturally based. Of course we cannot brand 70 cultures as all being similar; however, generally our students come to university with no background in reading in addition to their limited writing skills. In fact, while determining their literacy skills each term I also take a brief poll to establish how much interest they have in reading. Every term I discover the same thing: less than $10 \%$ of all my students (one or two in each class) have ever read an entire book in their lives, and this includes in their own language. This was shocking to me when I first started teaching here. I could not believe students had not had the opportunity somewhere in life to have read a whole book; readers from elementary school don't count. The response has continued to be the same over the past six years. About four years ago, I designed an activity that I hoped would change the way they view reading. I call it the Reading Project.

\section{The Reading Project}

This project is a function of the students' lives from day one in my classroom. I have used it in each of the courses I teach. It is on the syllabus and discussed thoroughly early in the semester and throughout the term. By the fourth week of class, every student must have chosen a book that he or she plans to read during the semester. Choosing the book is part of the assignment. It is incumbent upon them to go to the library, talk to their peers to discover titles, or do whatever they must to find suitable reading material. This helps them in two ways: by researching they gain some prior knowledge and by being in charge they are empowered. The book itself must be at least one hundred pages. I approve every book because part of the assignment is a presentation and some books have content that students end up being embarrassed to discuss in front of their peers. Culture also plays an important role in this instance. I must be sensitive to the many cultures in my classroom. I certainly do not want to put my students, either as presenters or audience members, into a situation where they may be uncomfortable. I only ask that students bring me a copy of the book if it is something I am unfamiliar with. Books may be fiction or non-fiction. I try to steer them towards fiction because I want their first experience reading a book to be "fun." Often when reading non-fiction, students become bogged down in terminology and then lose interest in the "story." However, I have had some success with students reading autobiographies or biographies, often about 
leaders from their own countries. This genre of books captures their attention and I certainly encourage that interest and curiosity.

\section{What Are Students Expected to Do Next?}

In addition to the information provided on the syllabus, an assignment sheet is posted on the iLearn forum, giving detailed information about the task. Due to my students' lack of experience with reading a complete book, I ensure that they have numerous opportunities to remain actively connected with this assignment during the semester through reading and writing. This is done using several methods, but the most engaging for them is the Discussion Board on iLearn. Every week students are expected to post something about their book: what they have discovered interesting about the topic, the author, the story, their recommendations for other students, and how they feel about the assignment. It is an open forum for them to discuss their books. I further expect them to respond to their peers and give positive or helpful feedback using academic language. Employing this method helps me know who is making progress with the assignment. Another way I use to determine if students are progressing is to have brief discussions every few weeks about the assignment focusing on concerns. This gives students another means of voicing any anxieties with an assignment which some view as overwhelming due to its uniqueness in their lives.

The books are completed by the last month of the term. During the last two weeks of classes, students make brief informal presentations of their books. Students have up to four minutes to briefly remind us of the title, author, and the plot, as this has been discussed on iLearn. Presenters then reflect on their book. This is especially important as the final write up includes both a summary and a reflection. By encouraging them to speak out reflectively at this point, they are better equipped to deal with the notion of "reflection." Students finish their presentations by recommending the book (or not) to their peers and giving their rationale.

Following the presentations a written summary of the book and a reflection are due. The students are given a two-page limit for each. Although initially they cannot imagine being able to summarize a book in just two pages, after writing summaries throughout the semester, they realize it is possible. What I am most pleased with is that these final summary/reflections often turn out to be some of their best writing all year. The consistent engagement with their books encourages them to take pride in ensuring the story is clear to their readers, and they also seem to reflect more deeply on this assignment than others. As bilingual writers they often face difficulties in making their voices heard through their writings; however, with the book project, due to the time invested, their voices are usually very clear and reveal an admirable ability to write and share their personal thoughts through the written word.

\section{What are the Results of this Venture?}

The final results of the project vary from semester to semester. However, generally I find that this assignment is a motivator in terms of getting students interested in reading, which leads to better writing. Some of the input I receive during their presentations indicates that a few of the students are thrilled to have discovered books. 
I have actually had students tell the class that it was such a great adventure that they planned to read their chosen author's other books. This happened last year after a student finished Khaled Hosseini's The Kite Runner, she was excited to read his second novel $A$ Thousand Splendid Suns. Another important point is that many of the students end up choosing authors who are writing in a second language. Again, this leads to empowerment because they can find others, like themselves, who have become successful writers and who are able to manipulate the written word in English. For many of them, this is inspirational and encourages better writing on their part.

When I get positive feedback I am excited that in some small way I may have promoted the birth of a future reader. Many times students will thank me for encouraging them to read and some admit it "wasn't so bad." However, I will also have those who claim the process was "boring," but that is expected. What heartens me is that when we get those responses other students will disagree, telling their "bored" peers that they chose a "bad" book and they should keep trying.

Perhaps the best part of the project is the broader picture. Although I am pleased to promote reading and perhaps turn a few non-readers into new readers, what I am also doing is taking learners from nations across the globe and showing them that reading is a must, a gift, a part of life that they can use and enjoy worldwide and is an important part of becoming better writers. I encourage the expansion of prior knowledge and the students recognize what I am doing. They understand they must actively seek it, and, through reading books, they discover an excellent method of gaining some much-needed knowledge. I am convinced of this assignment each term because I see how it helps students, from all over the world carrying their cultures, languages, and identities, into a writing classroom that challenges them to do something many have never done. The project does not just encourage reading in order to be quizzed on the topic or the vocabulary; it is not about reading to write to a prompt or for an exam. Instead, it is a project that engages them, that empowers them from the first step by choosing their books, giving them that important opening to interact with a text over an extended period and finally looking forward to where the story is going. They realize that, once that story is told, they have to take it and make it come alive for their own audience. The students take pride in their books and therefore they want to be proud of the writing that comes forth for this assignment; most of them are very successful. This is a project that I can honestly say helps my multicultural learners hone and develop their writing skills. It happens because it is a consistent and long term assignment that encourages their active participation and leads to many benefits including: enjoyment, empowerment, new knowledge, new vocabulary, and, perhaps most importantly, pride in completing an entire book.

\section{Conclusion}

As mentioned, some of my students' best writing follows their book project. I strongly believe that their interest in this project is what drives them. Their writing improves because they engage with their books in a way that some are never able to with the shorter texts read throughout the semester. The discovery of bilingual authors reveals to them the possibilities of becoming good writers in their second language. They 
feel empowered from the beginning of the project by being in charge of their learning and what they choose to read. Furthermore, they realize the importance of developing background knowledge in order to help them become critical readers. Critical reading becomes a reality with their own book in a way that is not so easily attained with shorter assignments. I am pleased that this project promotes two important components of our writing curriculum: reading and writing. And in the end, I can sometimes measure success of the assignment in just a simple "thank you" from a few students for revealing to them the beauty of reading and books.

\section{Works Cited}

Al-Issa, Ahmad, and Laila Dahan. "Prior Knowledge and Writing in the College EFL Composition Classroom." Teaching Writing Skills in EFL: Theory, Research and Pedagogy. Ed. Christine Coombe, Adel Jendli, and Peter Davidson. Dubai: TESOL Arabia Publications, 2008. 17-26.

Eskey, David. "Holding in the bottom: An interactive approach to the language problems of second language readers." Interactive Approaches to Second Language Reading. Ed. Patricia Carrell, Joanne Devine, and David E. Eskey. Cambridge: Cambridge UP, 1988. 93-100.

Li, Xuemei. "Souls in Exile: Identities of Bilingual Writers." Journal of Language, Identity, and Education 6.4 (2007): 259-275.

Nicolaidis, Christos S., and Evangelia Koutroumpezi. "Empowerment in Tertiary Education: A Strategic Source of Learning Advantage." Industry and Higher Education 22.3 (2008): 183-188.

Reid, Joy. "Historical perspectives on writing and reading in the ESL classroom." Reading in the Composition Classroom: Second Language Perspectives. Ed. Joan Carson and Ilona Leki. Boston: Heinle and Heinle Publishers, 1993. 33-60. Tierney, Robert, and P. David Pearson. "Toward a Composing Model of Reading." Language Arts 60 (1983). 568-580.

Tropiano, Carmelo. "Paulo Freire, Social Change, and the Teaching of Gothic Literature." College Quarterly 11.2 (2008). 20 December $2009<$ http://www. senecac.on.ca/quarterly/2008-vol11-num02-spring/tropiano.html>.

Laila Dahan teaches writing at the American University of Sharjah in the UAE. She holds MA's in International Relations and TESOL. She is currently working on her doctoral dissertation. Her research interests and publications are in: language and identity, global English, cross-cultural communication, and teaching writing. Currently she is co-editing a book on global English in the Arab World. 